\title{
複合型ニューラルネットワークについて*
}

\author{
中谷 智広**.山本 裕 ${ }^{* * *} \cdot$ 松 本 豊***
}

\section{On Composite Neural Networks*}

\author{
Tomohiro Nakatani**, Yutaka Yamamoto***and Yutaka Matsumoto***
}

\begin{abstract}
In this paper, we consider neural networks with three layers, where each unit itself is allowed to be a neural network with learning completed. (In the follwing, such neural networks are referred to as composite neural networks.) Existing neural networks are constructed for a single purpose, so that they cannot be used for more complicated information processing without teaching them from the beginning, while composite neural networks reuse these neural network resources. In composite neural networks, network units are connected by new synapses and only these weights are subject to updating through learning. This paper presents learning algorithms for composite neural networks with and without feedback in the middle layer. Two numerical examples are shown in the fields of logical circuit and alphabet recognition. Methods of interpolation learning, which is important for composite neural networks, are also given for each example.
\end{abstract}

\section{1.はじめに}

Rumelhart らが, 階層フィードフォワード型ネット ワークの学習法である誤差逆伝播法 ${ }^{1)}$ を提案して以来, その学習能力の高さから, 階層型ネットワークは各分野 でパターン認識の応用が試されてきた ${ }^{2), 3)}$.これに対し, 最近, 従来の階層型ネットワークにフィードバック結合 を加えた, リカレンネットワークの研究が行われてい $3^{4) \sim 8)}$. このネットワークは, より一般的なネットワー ク構造であるため高い学習能力を持ち, ダイナミカルな 時系列デー夕あ容易に学習できることなどが確認されて いる.

これまで, 文字認識やロボットアームの制御など個別 の問題を解く時のニューラルネットワークの有効性は確 認されてきた2),3). しかし，そのネットワークは学習し た問題を解くためだけにしか使えず，生産性の低いもの である.フィードバック結合を持つネットワークでも, きわめて大規模な問題を学習する場合, ネットワークが

* 原稿受付 1991.9.8.

** 日本電信電話(㑣)

*** 京都大学工学部 Division of Applied Systems Science, Faculty of Engineering, Kyoto University, Kyoto 606, JAPAN

Key Words : Neural networks, composite networks, interpolated units, learning algorithms.
全く白紙の状態加ら学習させるのは, 効率む悪くなる 上，収束する率屯低下する，これに対して，問題を幾つ かの小部分に分割し, その各々について学習を行った後 に全体を統合するという考え方に立てば，個々のネット ワークの効率や複合されたネットワーク（以下, 複合型 ネットワークと呼ぶ）の学習速度の向上ばかりではな く, より高度な情報処理の実現も可能である ${ }^{9)}$. 複合型 ネットワークは, 素子がニューラルネットワークばかり ではなく，任意の関数やダイナミカルシステムであるよ うな場合にまで拡張することができる.

本研究では, 複合型ニューラルネットワークを考え, フィードバック結合のある場合とない場合について，そ の学習アルゴリズムを与え，その有効性を示す．また， 複合型ネットワークを構成するにあたり, 個々のネット ワークにおいて重要と考えられる汎化学習の概念につい て述べ，具体的にその方法を数值例に即して与える.

本論文の構成は以下のとおりである. まず, 2. で複合 型ネットワークの学習アルゴリズムを与える. 3. で汎化 学習について述べ, 論理回路の生成とアルファベット文 字の確認に関する数值実験を行う. 最後に, 4. で本研究 のまとめ, 今後の課題について触れる.

\section{2. 複合型ネットワークの学習則}

本研究で扱う複合型ネットワークとは, 中間層内に 
フィードバック結合をもつ 3 層型ニューラルネットワー クで, しかも中間層・出力層の素子が単なるニューロン に限らず，学習済のニューラルネットワーク自身をも許 すネットワークである (Fig. 1 参照).ここで, 4 層以上 からなる複合型ネットワークも，中間層に含めることに より, 3 層型ネットワークで表現できることに注意する. 以下では，既学習のニューラルネットワークが使われて いる素子を特にネットワーク素子と呼ぶ。

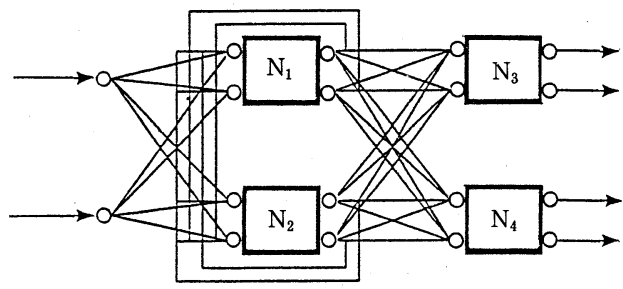

Input layer middle layer Output layer

Fig. 1 Composite neural network

複合型ネットワークは同期的に挙動し, 1 単位時間は ネットワーク素子のうち処理時間が 1 番長いものに準ず ると仮定する. 複合型ネットワークを一般的なダイナミ カルシステムとして取り扱うために, 各素子は状態変数 を持つあのとする.これにより, 離散時間リカレント ネットワークを一つのネットワーク素子として扱うこと もできる.

複合型ネットワークの状態方程式を記述するために, 次の記号を導入する :

$\boldsymbol{w}_{i j}^{* *}: j$ 番目の素子から $j$ 番目の素子へのシナプス荷 重行列（ここで, ネットワーク素子が多入力多出力であ れば, $\boldsymbol{w}_{i j}^{* *}$ は一般に行列となることに注意する. 右肩の 添字**は $M I$ : 入力層一中間層, $M M$ : 中間層内, $O M$ : 中間層一出力層間のいずれか.）

$\boldsymbol{u}_{i}^{*}(t)$ : 時刻 $t$ における $i$ 番目の素子への入力ベクト ル (右肩の添字* $* I$ : 入力層, $M$ : 中間層, $O$ : 出力層 のいずれか. 以下同様. )

$\boldsymbol{x}_{i}^{*}(t)$ : 時刻 $t$ における $i$ 番目の素子の状態ベクトル

$\boldsymbol{y}_{i}^{*}(t)$ : 時刻 $t$ における $i$ 番目の素子からの出力ベク トル

$\boldsymbol{f}_{i}^{*}: i$ 番目の素子における状態遷移関数

$\boldsymbol{g}_{i}^{*}: i$ 番目の素子における出力関数

簡単化のため, 入力層の素子で線形入出力を仮定する と, 複合型ネットワーク状態方程式は以下のように記述 できる：

中間層 $i$ 番目の素子

$$
\begin{aligned}
& \left.\boldsymbol{x}_{i}^{M}(t)=\boldsymbol{f}_{i}^{M}\left(\boldsymbol{x}_{i}^{M}(t-1)\right), \boldsymbol{u}_{i}^{M}(t-1)\right) \\
& \boldsymbol{y}_{i}^{M}(t)=\boldsymbol{g}_{i}^{M}\left(\boldsymbol{x}_{i}^{M}(t)\right)
\end{aligned}
$$

出力層 $\mathrm{i}$ 番目の素子

$$
\begin{aligned}
& \boldsymbol{x}_{i}^{O}(t)=\boldsymbol{f}_{i}^{O}\left(\boldsymbol{x}_{i}^{O}(t-1), \boldsymbol{u}_{i}^{O}(t-1)\right) \\
& \boldsymbol{y}_{i}^{O}(t)=\boldsymbol{g}_{i}^{O}\left(\boldsymbol{x}_{i}^{O}(t)\right)
\end{aligned}
$$

素子間の結合

$$
\left\{\begin{array}{l}
\boldsymbol{u}_{i}^{M}(t)=\sum_{j}\left\{\boldsymbol{w}_{i j}^{M I} \boldsymbol{y}_{j}^{I}(t)+\boldsymbol{w}_{i j}^{M M} \boldsymbol{y}_{j}^{M}(t)\right\} \\
\boldsymbol{u}_{i}^{O}(t)=\sum_{j}\left\{\boldsymbol{w}_{i j}^{O M} \boldsymbol{y}_{j}^{M}(t)\right.
\end{array}\right.
$$

複合型ネットワークにおける学習とは, ネットワーク 素子内の構造(シナプス荷重)を固定したままで，素子間 のシナプス荷重を変化させることにより，ネットワーク の出力を目標值に近づけることを意味する. まず, 2.1 でフィードバック結合をも許す一般的な複合型ネット ワークに対する学習則を与える，さらに，中間層の素子 間にフィードバック結合のない場合には，誤差逆伝播法 を用いることにより，より少ない学習回数での収束が期 待されるため, 2.2 でその方法について触れる.

\section{1 フィードバック結合のある場合}

フィードバック結合を有する場合, 複合型ネットワー クは時系列データを学習することができる，簡単化のた め, 初期条件を $\boldsymbol{x}_{i}^{M}(1)=0, \boldsymbol{x}_{i}^{O}(1)=0$ とすると, 長さ $l$ の時系列入力の場合, 入力は $t=1 \sim l$, 出力は $t=3 \sim l+$ 2 に対してのみ意味がある.

評価関数はいろいろ考えられるが, 本研究では次の関 数を用い学習則を説明する：

$$
V(\Omega)=\frac{1}{2} \sum_{t=3}^{l+2} \sum_{i}\left\|\boldsymbol{y}_{i}^{O}(t)-\boldsymbol{d}_{i}(t)\right\|^{2}
$$

ここで, $\Omega$ は素子間のシナプス結合の集合, $\|\cdot\|$ はユ一 クリッド距離, $\boldsymbol{d}_{i}(t)$ は出力層の素子 $i$ における時刻 $t$ の 教師信号を表わす.

いま, $\eta(>0)$ を学習係数とし， $\Omega$ に属する任意のシナ プス荷重を $\omega$ とおくと,

$$
\begin{aligned}
\frac{\partial V(\Omega)}{\partial \omega} & =\sum_{t=3}^{l+2} \sum_{i}\left\langle\boldsymbol{y}_{i}^{O}(t)-\boldsymbol{d}_{i}(t), \frac{\partial \boldsymbol{y}_{i}^{O}(t)}{\partial \omega}\right\rangle \\
\omega & =\omega-\eta \frac{\partial V(\Omega)}{\partial \omega}
\end{aligned}
$$

とする. $\eta$ が十分小さいとき，(8)式を用いて，

$$
\begin{aligned}
\Delta V & \simeq \frac{\partial V(\Omega)}{\partial \omega} \cdot \Delta \omega \\
& =-\eta\left(\frac{\partial V(\Omega)}{\partial \omega}\right)^{2} \\
& <0
\end{aligned}
$$

であるから，(7), (8)式による更新で, 評価関数 $V(\Omega)$ を 逐次的に減少させることができる。（7)式の右辺を計算 するためには, $\boldsymbol{y}_{i}^{O}(t)(t=3, \cdots, l+2)$ とその $\omega(\omega \in \Omega) に$ 
関する勾配を求める必要がある.

（1）（5)を $\omega$ で微分することにより，次式を得る：

$$
\begin{aligned}
\frac{\partial \boldsymbol{x}_{i}^{M}(t)}{\partial \omega}= & \left\{\nabla_{x} \boldsymbol{f}_{i}^{M}\left(\boldsymbol{x}_{i}^{M}(t-1), \boldsymbol{u}_{i}^{M}(t-1)\right)\right\}^{T} \\
& \cdot \frac{\partial \boldsymbol{u}_{i}^{M}(t-1)}{\partial \omega} \\
& +\left\{\nabla_{x} \boldsymbol{f}_{i}^{M}\left(\boldsymbol{x}_{i}^{M}(t-1), \boldsymbol{u}_{i}^{M}(t-1)\right)\right\}^{T} \\
& \cdot \frac{\partial \boldsymbol{x}_{i}^{M}(t-1)}{\partial \omega} \\
\frac{\partial \boldsymbol{y}_{i}^{M}(t)}{\partial \omega}= & \left\{\nabla_{u} \boldsymbol{g}_{i}^{M}\left(\boldsymbol{x}_{i}^{M}(t)\right)\right\}^{T} \frac{\partial \boldsymbol{x}_{i}^{M}(t)}{\partial \omega} \\
\frac{\partial \boldsymbol{x}_{i}^{O}(t)}{\partial \omega}=\left\{\nabla_{u} \boldsymbol{f}_{i}^{O}\left(\boldsymbol{x}_{i}^{O}(t-1), \boldsymbol{u}_{i}^{O}(t-1)\right)\right\}^{T} & \cdot \frac{\partial \boldsymbol{x}_{i}^{O}(t-1)}{\partial \omega} \\
& +\left\{\nabla_{x} \boldsymbol{f}_{i}^{O}\left(\boldsymbol{x}_{i}^{O}(t-1), \boldsymbol{u}_{i}^{O}(t-1)\right)\right\}^{T} \\
& \cdot \frac{\partial \boldsymbol{u}_{i}^{O}(t-1)}{\partial \omega} \\
\frac{\partial \boldsymbol{y}_{i}^{O}(t)}{\partial \omega}= & \left\{\nabla_{u} \boldsymbol{g}_{i}^{O}\left(\boldsymbol{x}_{i}^{O}(t)\right)\right\}^{T} \frac{\partial \boldsymbol{x}_{i}^{O}(t)}{\partial \omega} \\
\frac{\partial \boldsymbol{u}_{i}^{M}(t)}{\partial \omega}= & \sum_{j}\left(\frac{\partial \boldsymbol{w}_{i j}^{M I}}{\partial \omega} \boldsymbol{y}_{j}^{I}(t)+\frac{\partial \boldsymbol{w}_{i j}^{M M}}{\partial \omega} \boldsymbol{y}_{j}^{M}(t)\right. \\
\frac{\partial \boldsymbol{u}_{i}^{O}(t)}{\partial \omega}= & \sum_{j}\left(\frac{\partial \boldsymbol{w}_{i j}^{O M}}{\partial \omega} \boldsymbol{y}_{j}^{M}(t)+\boldsymbol{w}_{i j}^{O M} \frac{\partial \boldsymbol{y}_{j}^{M}(t)}{\partial \omega}\right)
\end{aligned}
$$

ここで，右肩の $T$ は転值を表わす。

以上の式を用いて，フィードバック結合を有する場合 の複合型ネットワークの学習アルゴリズムは次の手順で 与えられる：

Step 1 : 更新すべきシナプス荷重 $\omega$ を $\Omega$ から適当に選 s.

Step 2：初期条件を

$$
\left\{\begin{array}{l}
\boldsymbol{x}_{i}^{M}(1)=0 \\
\boldsymbol{x}_{i}^{O}(1)=0 \\
\frac{\partial \boldsymbol{x}_{i}^{M}(1)}{\partial \omega}=0 \\
\frac{\partial \boldsymbol{x}_{i}^{O}(1)}{\partial \omega}=0
\end{array}\right.
$$

と設定する.

Step 3 : 時刻 $t(\geq 2)$ において, $\boldsymbol{x}_{i}^{M}(t-1), \boldsymbol{x}_{i}^{O}(t-1)$, $\frac{\partial \boldsymbol{x}_{i}^{M}(t-1)}{\partial \omega}, \frac{\partial \boldsymbol{x}_{i}^{O}(t-1)}{\partial \omega}$ がすでに求まってい
るとき，(2)，(5)，(1)，(3)，(4) 式の順序で, $\boldsymbol{x}_{i}^{M}(t), \boldsymbol{x}_{i}^{O}(t), \boldsymbol{y}_{i}^{O}(t)$ を求め, (10), (13), (9), (11), (12), 式の順序で, $\frac{\partial \boldsymbol{x}_{i}^{M}(t)}{\partial \omega}, \frac{\partial \boldsymbol{x}_{i}^{O}(t)}{\partial \omega}$, $\frac{\partial \boldsymbol{y}_{i}^{O}(t)}{\partial \omega}$ を求める.

Step $4: t \leq l+2$ なら $t=t+1$ とし, Step 3へ。それ以 外の場合は, Step 5 へ.

Step 5:(7), (8) 式の更新を行う.

Step 6: (6) 式を評価し, $V(\Omega)>\varepsilon(\varepsilon$ は許容誤差)なら, Step 1 亿，それ以外の場合は，終了する.

\section{2 フィードバック結合のない場合}

ネットワーク素子がすべてフィードフォワード型ネッ トワークであり，また中間層内の素子間に相互結合がな ければ, 複合型ネットワークの学習則として誤差逆伝播 法を利用できる．すなわち，フィードバック結合を全く 含まない複合型ネットワークは，Fig. 2 のように前方向 へのニューロンの結合のみで構成されているので, 誤差 逆伝播法により出力誤差信号を出力層加入力層の方向 に逆伝播させ，もしある結合がネットワーク素子内の屯 のであればそのシナプス荷重を更新せず，素子間の結合 であればその荷重を更新する。このようにすれば，ネッ トワーク素子内のシナプス荷重を更新する事なく，素子 間結合の更新に必要な後層からの誤差を前方向へと伝播 させることができる。

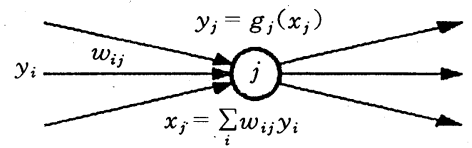

Fig. 2 Neuron and synapses

具体的には，素子間結合の集合を $\Omega$, 第 $l-1$ 層の ニューロン $i$ から第 $l$ 層のニューロン $j$ へのシナプス荷 重を $w_{i j}^{l}$, 第 $l$ 層のニューロン $i$ での入力, 出力関数, 出 力, 誤差をそれぞれ $u_{i}^{l}, g_{i}^{l}, y_{i}^{l}, \delta_{i}^{l}$, 出力層の二ューロ ン $i$ での入力, 出力関数, 出力, 誤差, 教師信号をそれぞ れ $u_{i}^{O}, g_{i}^{O}, y_{i}^{O}, \delta_{i}^{O}, d_{i}$, 学習係数を $\eta$ とおくと,

$$
\begin{aligned}
& \delta_{j}^{o}=\left(\left.\frac{d}{d u} g_{j}^{O}(u)\right|_{u=u_{j}^{o}}\right) \cdot\left(y_{j}^{O}-d_{j}\right) \\
& \delta_{j}^{l}=\left(\left.\frac{d}{d u} g_{j}^{l}(u)\right|_{u=u_{j}^{l}}\right) \cdot \sum_{k} \delta_{k}^{l+1} w_{j k}^{l+1} \\
& w_{i j}^{l}= \begin{cases}w_{i j}^{l}-\eta \cdot \delta_{j}^{l} \cdot y_{i}^{l-1}, & \text { for } w_{i j}^{l} \in \Omega \\
w_{i j}^{l}, & \text { for } w_{i j}^{l} \notin \Omega\end{cases}
\end{aligned}
$$

の手順により学習できる. 


\section{3. 数值実験}

数値実験として, 複合型ネットワークを論理回路の生 成およびアルファベット文字の認識に適用した例を示 す. 各素子での出力関数として, シグモイド関数

$$
g(x)=\frac{a}{1+e^{-x}}+b
$$

を用い, 特に断らない限り $a=1, b=0$ として実験を 行った. 各素子での評価関数 $E$ は次式を用いた：

$$
E=\frac{1}{2} \sum_{p} \sum_{i}\left\|\boldsymbol{y}_{i}^{O(p)}-\boldsymbol{d}_{i}^{(p)}\right\|^{2}
$$

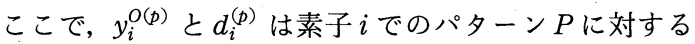
出力および教師信号である. ある最大学習回数に達する 以前に評価関数の值が $\varepsilon$ 以下に収束したとき, 学習は成 功したとし，それ以外の場合は学習失敗とした。

複合型ネットワークの学習に使う素子は，あともと何 らかの学習パターンを学習したあのであるから，その素 子に期待される特徴は学習データに集約されているとい える.しかし，離散的なデータを学習したネットワーク を素子として使うとき，未学習データに対する素子の入 力は未知であるため，素子の特徴を活かした複合型ネッ トワークができるとは限らない，そこで，学習デー夕以 外の入力に対しても，学習パターンの適当な補間を取っ た值を出力するように汎化した学習で素子を作りその素 子を使って複合型ネットワークを構成すれば，より素子 の特徴を活かした学習が出来るのではないかと予想され る. 本研究では, この汎化した学習を行うことを汎化学 習と呼び，汎化学習で作られる素子のことを汎化素子と 呼ぶ, 数值実験では, 通常の学習による素子と汎化学習 した素子とで, 素子の特徴と学習結果を比較し, その特 徴がネットワークによ゙う影響しているかを考察した。

\section{1 論理回路の生成}

論理回路は，例えば AND，OR，NOT をうまく組み合 わすことにより任意の論理演算回路を構成でき，しかす その構成が論理的に明白であるので例題として取り扱い 易い. 本実験では，ある論理演算(NAND，AND，XOR） を学習させたネットワーク素子からなる複合型ネット ワークにおいて, AND 回路生成を試みた。

複合型ネットワークを Fig. 3(a) と (b)のように構成し 学習を行った。（a）の構成で，ネットワーク素子が NAND 演算子のとき, シナプス荷重がすべて 1 ならば, AND 回路が構成できることに注意する. その他の演算 子では AND 回路を作ることはできない，(b)は，各層間 のすべての端子間にシナプス結合がある場合であり，一 般の階層型ネットワークとしては，こちらの構成の方が
自然であるといえる.

通常の学習に対する結果を Table 1 に示す. NEU$\mathrm{RON}$ の闌は, 各素子がニューロンで, ネットワーク素 子でない場合を示している. 各ネットワーク素子は 3 層 フィードフォワード型ネットワークで, 中間層のニュー ロン数を 2 にして誤差逆伝播法を用いて学習させたもの である. 実際に用いた素子は，全学習パターンに対する 二乗䛊差の和が 0.01 程度のものであり, 完全な論理演 算子ではない，誤差がほぼ 0 の素子は, 学習パターンに 対する誤差が少ない分, それ以外のデー夕に対する入出 力が悪いため, 複合型ネットワークの学習には不都合で ある.

Table 1 から次のことが分かる.

・複合型ネットワークでは，一般の階層型ネットワー クで学習させた時と比較して，学習成功率は悪く なっている，その原因は，複合型ネットワークは ネットワーク固有の特殊性が強く, 素子によって学 習しやすいパターンとそうでないパターンが存在す ることにある.

・ (a)の構成では, NAND 素子を使ったとき最も学習 が成功している.これは, 論理回路の特質から考え て，NAND 素子が一番有利であると考えられるの と一致する.

Fig. 4 は,（a）の構成では, NAND 素子を使った複合 型ネットワークの学習後のシナプス荷重值と, 入力 (1.0，1.0）に対する反応を示す. Fig. 4 から, NAND 演 算子で AND を実現するような論理回路で構成可能なパ ターンを学習する場合, NAND 素子はネットワークの

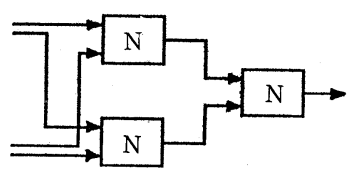

(a)

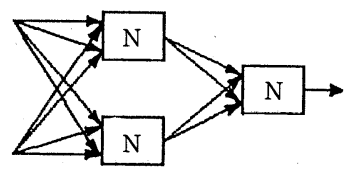

(b)

Fig. 3 Connection of network units

Table 1 Learning of AND operation by normal units

\begin{tabular}{|c|c|c|c|c|}
\hline & \multicolumn{2}{|c|}{ Connection (a) } & \multicolumn{2}{c|}{ Connection (b) } \\
\hline Unit & Success & Iteration & Success & Iteration \\
\hline NAND & $100 \%$ & 6500 & $90 \%$ & 85500 \\
\hline AND & $0 \%$ & - & $30 \%$ & 207333 \\
\hline XOR & $55 \%$ & 4727 & $5 \%$ & 1000 \\
\hline NEURON & $100 \%$ & 3000 & $100 \%$ & 3000 \\
\hline
\end{tabular}

Initial weights : $-0.1 \sim 0.1,20$ samples 
中で, 実際の NAND 回路の中の NAND ゲートと同様 の役割を担っていることが分かる. したがって，この例 のように問題が単純であれば，素子の学習をあまり工夫 しなくてあ，素子の特徴を活かした学習が行えることが わかる。

つぎに，汎化学習を行った素子について同様の実験を 行う．汎化素子を作る方法は，一般にデータの種類に依 存するので, すべての場合に有効な方法は存在しない， 本実験では，素子に学習パターンを与えるときに，入力 は, 用意されている学習パターンを乱数で定められた係 数で線形結合することにより与え, 教師信号は, 各々の 教師信号をそれぞれ同じ係数で線形結合することにより 学習させた，実際に用いた補間の方法では，素子の出力 は $[0,1]$ の範囲におさまらなくなるため, 各ニューロン のシグモイド関数 $((18)$ 式)を, 出力範用が $[-2,2]$ にな るように, $a=4, b=-2$ とした. 初期荷重は-0.1 0.1 程度の值とし，比較的小さな值にしなければならない。 これは，素子の汎化が行われているのが入力の $[0,1]$ 付近のみであるため，その範囲を越えた入力が素子に入 ることを避けるためである.

NAND, AND, XOR の汎化素子は, 中間層のニュー ロン数を 10 とし, 3 層フィードフォワード型ネットワー クで構成した。ここで, 通常の学習に比べて中間層の ニューロン数を多くしたのは, 汎化学習の方がより多く の情報を学習しなければならないことによる．汎化学習 では普通の学習に比べて誤差が小さくならず, どの素子 も 0.02 から 0.04 程度の誤差を含んでいる.

通常素子の場合と同様に, 複合型ネットワークが Fig. 3(a)と (b)のような二通りの構造を持つ場合について AND の学習を行い, その結果を Table 2 に示す. Table 2 から, 通常素子の場合 (Table 1) と比較して, 次のこと がいえる.

- 通常の素子の場合と同様に, NAND 素子が最も有

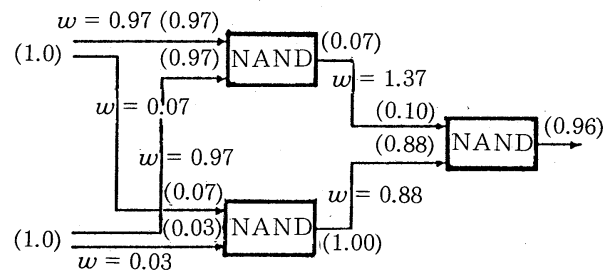

Fig. 4 Learning of AND operation by NAND units

Table 2 Learning of AND operation by interpolated units

\begin{tabular}{|c|c|c|c|c|}
\hline & \multicolumn{2}{|c|}{ Connection (a) } & \multicolumn{2}{c|}{ Connection (b) } \\
\hline Unit & Success & Iteration & Success & Iteration \\
\hline NAND & $100 \%$ & 110 & $100 \%$ & 2945 \\
\hline AND & $0 \%$ & - & $100 \%$ & 400 \\
\hline XOR & $30 \%$ & 700 & $100 \%$ & 300 \\
\hline
\end{tabular}

Initial weights : $-0.1 \sim 0.1,20$ samples
利に学習できている. また，(a)の構成では, NAND 以外の素子を用いたときの, 学習成功率が小さく なっていて, 素子の特徴がより明確に現れたことを 示している.

・学習回数が，通常の素子を使った場合の 10 分の 1 程度になっており, 汎化素子を用いて複合型ネット ワークを学習すれば，より少ない学習回数で学習が 成功することを示している.

・ (b)の構造をむつネットワークで学習させた場合, 汎化素子は通常素子と比べて, どの場合でも学習成 功率は高く, 学習回数む少ない, その理由は, (b)の 構成のネットワークでは NANDにより AND 回路 を論理的に構成できないが, 汎化学習によりネット ワークの表現の自由度が大きくなったため, 素子の $[0,1]$ の間の值を使っても学習ができるようになっ たことによる.

\section{2 アルファベット文字の認識}

アルファベット文字の認識を複合型ネットワークで行 う場合を考える. Fig. 5 に示すように，本実験で扱う複 合型ネットワークは，一層のニューロン層とすでに学習 を終えたアルファベット文字認識用ネットワークからな る.この複合型ネットワークでは, アルファベット認識 ネットワーク素子が, 文字認識を目的とする複合型ネッ トワーク内で, 全仕事の一端を担うことになるので, 一 つのネットワーク素子が様々なネットワークの部品とし て利用できる可能性を示すことになる.

本実験では, アルファベット文学に何らかの変換を加 えたデータを入力して与え, 教師信号として元のアル ファベットを与え, 正しく文字を認識するまで学習させ る. しかし, 単に学習できるだけではあまり意味がなく, 学習を終えた複合型ネットワークが, 実際にアルファ ベット認識素子の機能を利用し, ニューロン層が文字 データ変換フィルタとして働くように学習したのかどう かが問題となる. 言い換えると, 複合型ネットワークが 学習すべきことは, 学習データを作る際に, アルファ ベットに加えた変換の逆変換フィルタをニューロン層で 作ることである．あし逆変換フィルタが実現できれば;

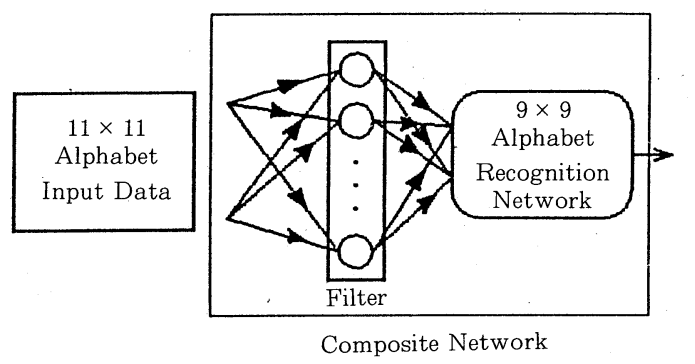

Fig. 5 Composite network for alphabet recognition 
この複合型ネットワークでは, 一つ一つの素子の機能を 活かすネットワークが構築されたといえる.

具体的に実験の設定について述べる. アルファベット 文字認識には A, B , C, H, I, J, K, L, の 8 文字を扱っ た.この 8 個の文字は，できる限り形の違う文字を選ぶ という理由で決められた(Fig. 6 参照). アルファベット 文字認識用ネットワークは 3 層フィードフォワード型で あり, 入力 $9 \times 9$ ビット, 中間層のニューロン数は 81 個, 出力は各文字に一つのニューロンを割り当てた.

アルファベット文字認識用ネットワークには汎化学習 を行い, 汎化素子とした. 汎化学習の方法は, 論理回路 の場合と同様である.ただし，入力データは学習パター ンと独立に決定するというのではなく，学習パターンに 適当にノイズを加えるという方法により得た. ニューロ ンのシグモイド関数 ((18) 式) は, 論理回路の時と同じ く $a=4, b=-2$ とした. このネットワーク素子は汎化 素子である上, アルファベット文字認識のような複雑な 問題を扱うため, デー夕を学習した後も誤差が大きく, 例えば A に反応すべき出力素子が, A が入力されても 0.6 から 0.8 程度の出力しか出さないというように, 完 全な学習は行えなかった。

上記のように汎化学習させたネットワーク素子を用い て, Fig. 5 の形の複合型ニューラルネットワークを構成 し, 次の学習を行った. 入力として $11 \times 11$ ビットのアル ファベット文字を与え，それがどの文字であるかを判別 し出力させた.

Fig. 7 にフィルの入出力に関する結果を示す. これ は, (19)式で与えられる学習誤差が 0.71 と, 汎化素子と して比較的精度の高いネットワーク素子を用いて, 全体 のネットワークの学習誤差が 0.008 になるまで学習した ときの結果である. Fig. 7(a)と (b)は，それぞれフィル 夕に学習パターン文字の一つである A と, 未学習パ ターン文字の S を入力したときの結果を示す. 横軸は $9 \times 9$ ビット文字の各ビット (=フィルタの各出力端子) に対応する 81 個の点を表わし, 縦軸はビット值 $(=$ フィ ルタの出力值)を表わす.フィルタに, あるアルファベッ トが入力されたときの出力值 $(=$ 文字認識ネットワーク 素子への入力值)を実線で示し, そのアルファベットを $9 \times 9$ で 表現したときの值 (ニネット ワーク素子への入力学習データ をつで示す. また，未学習デー

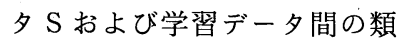
似度を Table 3 に与える。 ただ し, 類似度は二つの文字の $0-1$ 入力ベクトルの方向余弦と定義
する.

Fig. 7 および著者らの行ったその他の数值結果から, 以下の結論が導かれる.

・Fig.7(a)から，フィルタの出力がネットワーク素子 の学習入力データとほぼ一致しており,この複合型 ネットワークでは, フィルタの部分が $11 \times 11$ の文

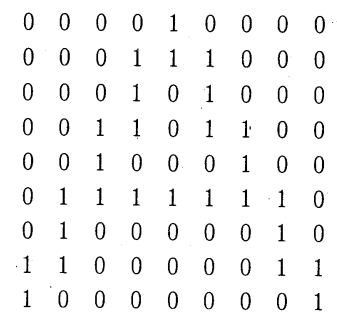

Fig. 6 Example of $9 \times 9$ bit patterns (A)

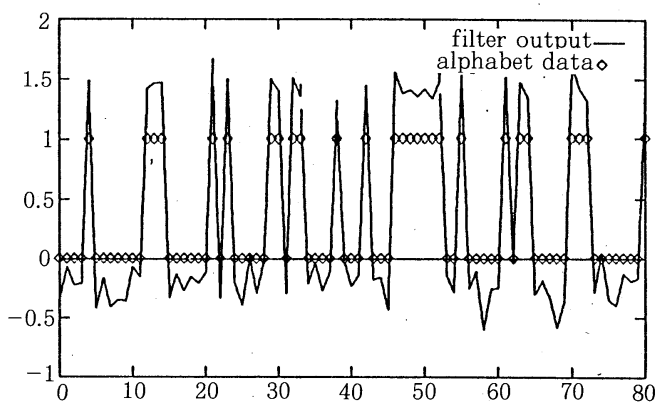

(a) learning data $\mathrm{A}$

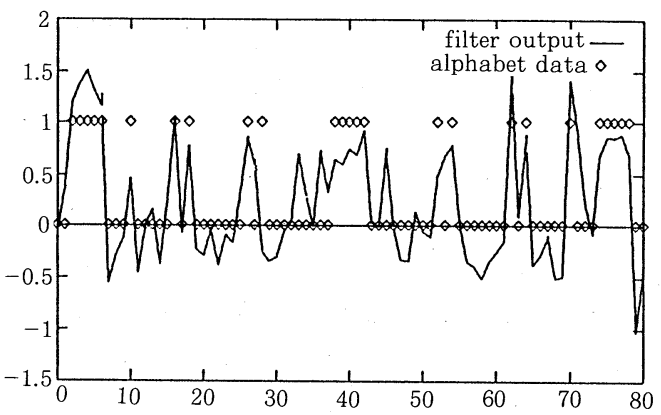

(b) not learning data $\mathrm{S}$

Fig. 7 Recognition of alphabet characters

Table 3 Direction cosine between input patterns

\begin{tabular}{|c|c|c|c|c|c|c|c|c|c|}
\hline direc. cos & A & B & C & H & I & J & K & L & S \\
\hline A & 1.000 & 0.227 & 0.139 & 0.243 & 0.131 & 0.141 & 0.286 & 0.111 & 0.206 \\
\hline B & - & 1.000 & 0.637 & 0.535 & 0.269 & 0.404 & 0.428 & 0.618 & 0.675 \\
\hline C & - & - & 1.000 & 0.325 & 0.255 & 0.446 & 0.306 & 0.502 & 0.687 \\
\hline H & - & - & - & 1.000 & 0.046 & 0.187 & 0.455 & 0.470 & 0.406 \\
\hline I & - & - & - & - & 1.000 & 0.215 & 0.087 & 0.169 & 0.315 \\
\hline J & - & - & - & - & - & 1.000 & 0.282 & 0.364 & 0.399 \\
\hline K & - & - & - & - & - & - & 1.000 & 0.48 & 0.177 \\
\hline L & - & - & - & - & - & - & - & 1.000 & 0.380 \\
\hline S & - & - & - & - & - & - & - & - & 1.000 \\
\hline
\end{tabular}


字を $9 \times 9$ の文字に変換するように学習したことが わかる。

・Fig. 7(b)から，学習した文字データほどではない が, 元のデータとフィルタの出力との間に相関関係 があるのがわかる.すなわち, 未学習文字に対して あ,フィル夕がある程度機能していることがわか る. このとき, Table 3 から明らかなように, 文字 $\mathrm{S}$ と文字 $\mathrm{B}, \mathrm{C}$ との間に $0.6 \sim 0.7$ 程度の類似度があ るため, 望ましい方向に作用したと推測される.こ のように, ある程度学習データに近い入力デー夕に ついては，汎化学習が有効であると考えられる。

・Fig. 7(a)と(b) は, 学習誤差が $1.0 \times 10^{-6}$ になるま で学習させてもその形状には変化がほとんどなかっ た。このことから, 汎化素子を用いた複合型ネット ワークでは, 過剩学習に対する影響をあまり受けず に, 素子の特徴を活かした学習が行われるといえ る.

・汎化素子ではなく, 通常に学習させた素子を用いて 学習を行った場合も, 汎化素子の場合とほぼ同様の 結果が得られる. ただし, 学習に時間がかかり, ネットワーク素子の精度よりも良い精度の学習は難 しく, たとえ学習に成功しても, フィル夕の出力と アルファベットデータの相関は小さなあのとなっ た.

\section{4. まとめ}

本研究では, 中間層にフィードバック結合をも許す 3 層複合型ニューラルネットワークを考え，その学習則を 与えた。この学習則は，ニューラルネットワークを非線 形ダイナミカルシステムと捉え, その構成が複合型の 時, 感度の計算法を与えることにより勾配法に帰着させ たものであるが，一方この学習法は，中間層にフィード バック結合がないときは, 本質的には内部に固定結合荷 重を持つ誤差逆伝播法とみなすこともできる.フィード バック結合の有無による損失を複合型の場合に論じるの は今後の課題としたい。なお複合型でない場合の比較に ついては参考文献 8)を参照されたい. さらに, 複合型 ネットワークにおけるネットワーク素子に, より柔軟性 を与えるための汎化学習の概念について述べ, その方法 を数值例に即して示した. 数值例として, 論理回路の生 成とアルファベット文字の認識を行った.

数值実験から, 通常の素子でも論理回路のような簡単 な問題では, 素子の機能を組方合わせた複合型ネット ワークを作ることが判明した。 さらに，文字認識のよう な比較的複雑な問題に対しても, 素子の機能をネット ワーク内部で利用するような, 複合型ネットワークが構
成されることが分かった。 また，汎化素子を用いれば， 過剩学習に対して屯素子の機能を活かした学習ができ た.

結論として, 本研究により, 複合型ネットワークで 個々の素子の機能を利用した複合作業を行うネットワー ク構築の可能性が示された。 したがって，すでに学習を 終えたニューラルネットワークを, 様々な複合型ネット ワークの部品として扱えるため, ネットワークの再利用 が可能となる. また, それらの部品の組み合わせによっ て, 比較的簡単に大規模なネットワークで構築できる可 能性がある.

複合型ネットワークに関する今後の課題として, 1) 汎 化学習とネットワークの適応性に関する理論的解明, 2) 与えられたネットワーク素子に対する組合せ問題とその 結果生じる機能性に関する研究などが挙げられる.

謝辞：本研究において有益な討論を頂いた沖野教郎教 授に感謝いたします。なお，本研究は一部文部省科学研 究費補助金一般研究（B） 02452180 の補助を受けた。記 して謝意を表する.

\section{参 考 文 献}

1) D. E. Rumelhart, J. L. McClelland and The PDP Research Group : Paraliel Distributed Processing, Vol. 1, Chapter 8, The MIT Press, pp. 318 362 (1986)

2) M. Kawato, K. Furukawa and R. Suzuki : A hierarchical neural-network model for control and learning of voluntary movement ; Biol. Cybern., No. 57, pp. 169 185 (1987)

3）加納, 川人, 鈴木：フィードバック誤差学習によるマニ ピュレータ逆キネマティックス, 逆ダイナミクス学習シ ミュレーション；信学技報 MBE88-171 (1988)

4) 河村：ダイナミカルシステムとしてのニューロン回路の学 習; 計測自動制御学会第 11 回 Dynamical System Symposium 予稿集, pp. 205 210 (1988)

5）佐藤：リカレントニューラルネットワークの学習アルゴリ ズム；信学技報 NC89-32（1989）

6) M. Sato: A Learning Algorithm to Teach Spatiotemporal Patterns to Recurrent Neural Networks ; Biol. Cybern., No. 62, pp. 259 263 (1990)

7）銅谷：ニューラルネットワークによる振動パターンの記 憶; Computrol, No. 29, pp. 52〜62（1990）

8）加藤, 山本：フィードバック結合を含むニューラルネット ワークの学習について; システム制御情報学会論文誌 Vol. 4, No. 9, pp. 23〜28 (1991)

9）伊集院，鈴岡：ニューラルネットワークの文書処理への応 用; システム/制御/情報, Vol. 35, No. 1, pp. 26〜31 (1991) 
